\title{
Platelet granule exocytosis: a comparison with chromaffin cells
}

\section{Jennifer L. Fitch-Tewfik and Robert Flaumenhaft*}

Division of Hemostasis and Thrombosis, Department of Medicine, BIDMC, Harvard Medical School, Boston, MA, USA

\section{Edited by:}

Rafael Vazquez-Martinez, University of Cordoba, Spain

\section{Reviewed by:}

Ricardo Borges, University of La

Laguna, Spain

Joshua J. Park, University of Toledo

College of Medicine, USA

\section{*Correspondence:}

Robert Flaumenhaft, Center for Life Science, Beth Israel Deaconess

Medical Center, Room 939, 3 Blackfan Circle, Boston, MA 02215, USA

e-mail: rflaumen@bidmc.harvard.edu
The rapid secretion of bioactive amines from chromaffin cells constitutes an important component of the fight or flight response of mammals to stress. Platelets respond to stresses within the vasculature by rapidly secreting cargo at sites of injury, inflammation, or infection. Although chromaffin cells derive from the neural crest and platelets from bone marrow megakaryocytes, both have evolved a heterogeneous assemblage of granule types and a mechanism for efficient release. This article will provide an overview of granule formation and exocytosis in platelets with an emphasis on areas in which the study of chromaffin cells has influenced that of platelets and on similarities between the two secretory systems. Commonalities include the use of transporters to concentrate bioactive amines and other cargos into granules, the role of cytoskeletal remodeling in granule exocytosis, and the use of granules to provide membrane for cytoplasmic projections. The SNAREs and SNARE accessory proteins used by each cell type will also be considered. Finally, we will discuss the newly appreciated role of dynamin family proteins in regulated fusion pore formation. This evaluation of the comparative cell biology of regulated exocytosis in platelets and chromaffin cells demonstrates a convergence of mechanisms between two disparate cell types both tasked with responding rapidly to physiological stimuli.

Keywords: exocytosis, granules, platelets, chromaffin system, cytoskeleton, dynamins, SNAREs

\section{INTRODUCTION}

Platelets are small, anucleate blood cells derived from bone marrow megakaryocytes. They are best known for their central role in maintaining the integrity of the vasculature (hemostasis) and for their pathological role in clotting arteries and veins (thrombosis) during myocardial infarction, stroke, peripheral vascular disease, and deep vein thrombosis. In addition to their role in hemostasis, platelets have also been proposed to function in many other aspects of host defense. Stimulus-induced release of platelet granules contributes to nearly all platelet functions including hemostasis and thrombosis, inflammation, angiogenesis, and anti-microbial activities (Blair and Flaumenhaft, 2009). Platelets contain three granule types: $\alpha$-granules, dense granules, and lysosomes (Figure 1; Table 1). Absence of dense granules, as observed in inherited syndromes such as Hermansky-Pudlak syndrome or Chediak-Higashi syndrome, results in a bleeding diathesis (Hermansky and Pudlak, 1959). Absence of $\alpha$-granules, as observed in gray platelet syndrome, also increases bleeding (Buchanan and Handin, 1976; Costa et al., 1976). The bleeding phenotype associated with these disorders underscores the importance of platelet granules in hemostasis.

Despite the functional importance of platelet granule secretion in maintaining vascular integrity and promoting host defense, the molecular basis of platelet granule secretion remained poorly studied until the late 1990s, despite transformative advances in secretion biology that had occurred over the preceding decade (Rothman and Orci, 1992; Sollner et al., 1993). This knowledge deficit was due in part to the fact that platelets are anucleate, complicating the use of standard molecular biological approaches that have been widely used to study regulated secretion in nucleated cells. In addition, the small size (2-3 $\mu \mathrm{m}$ in diameter) and unusual membrane system of the platelet prevented application of classic electrophysical approaches such as patch-clamp studies. Earlier studies evaluating the molecular mechanisms of platelet granule secretion relied on applying knowledge derived from other systems to the study of platelets. The chromaffin cell has been influential in this regard. Although these two cell types have different embryonic derivations and functions, both cells store bioactive amines and peptides at high concentrations and release their cargos rapidly in response to stress signals (Table $\mathbf{1}$ ). The study of platelet granule secretion has matured considerably over the past decade, making relevant a comparison of the mechanisms by which platelets and chromaffin cells store and release their granule contents in response to environmental signals.

\section{PLATELET GRANULE TYPES $\alpha$-GRANULES}

$\alpha$-Granules are by far the most abundant platelet granule type (Figure 1). There are $\sim 50-80 \alpha$-granules/platelet, ranging in size from 200 to $500 \mathrm{~nm}$. They comprise roughly $10 \%$ of the platelet volume, 10 -fold more than dense granules. $\alpha$-Granules contain a variety of membrane proteins and soluble cargo that give them a distinct appearance when stained with osmium and viewed by transmission electron microscopy (TEM). Proteomic analyses indicate that these granules contain hundreds of different types of proteins (Coppinger et al., 2004; Piersma et al., 2009). Protein cargos found in $\alpha$-granules include neuroactive peptides that are more typically associated with chromaffin cells, including tachykinins 
and enkephalins (Graham et al., 2004). Conversely, proteomic studies suggest that chromaffin large dense-core vesicles (LDCVs) contain several major constituents of $\alpha$-granules that can act in the vasculature, including platelet basic protein precursor, TGF- $\beta$, collagen isoforms, and metalloproteases (Table 2) (Wegrzyn et al., 2010). As with chromaffin cells, the mechanisms by which proteins are packaged in platelet storage granules are incompletely understood.

Platelet $\alpha$-granule cargos can include coagulants and anticoagulants, angiogenic and antiangiogenic factors, proteases and proteases inhibitors, and proinflammatory and anti-inflammatory

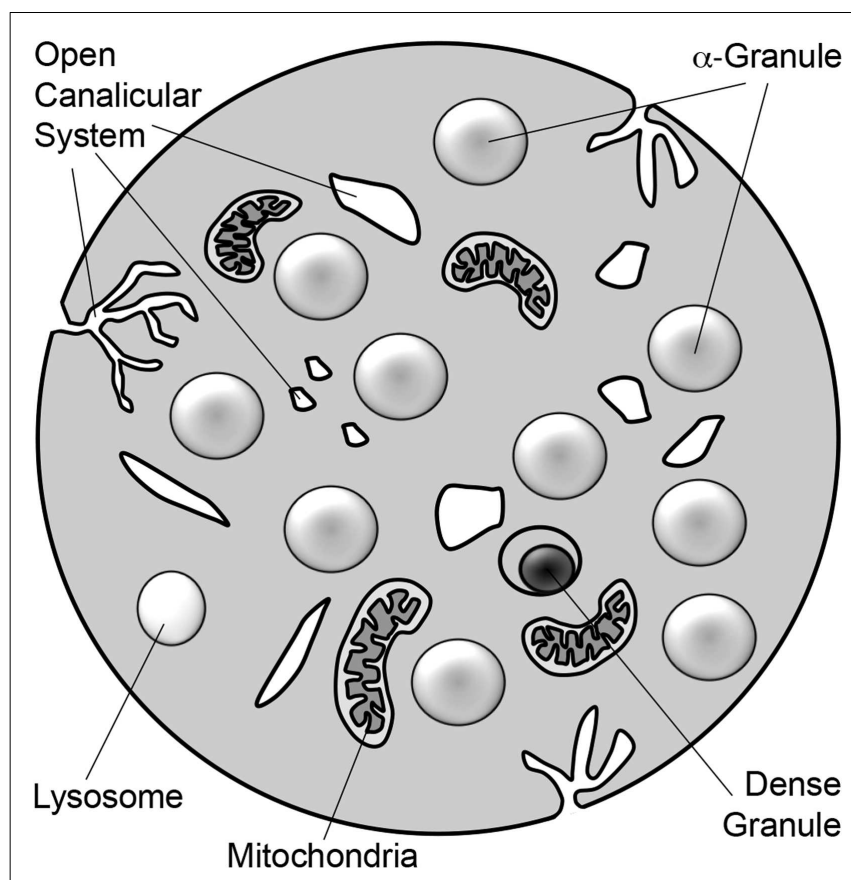

FIGURE 1 | Schematic diagram of platelet. The platelet is a 2-3 $\mu \mathrm{m}$ discoid cell that contains $\alpha$-granules, dense granules, and lysosomes. Platelets also contain mitochondria. Tunnel invaginations of the plasma membrane forms a complex membrane network, termed the open canalicular system, that courses throughout the platelet interior. Platelet granule secretion is thought to occur through fusion of granules with either the plasma membrane or the open canalicular system. mediators. This observation has raised the question of how $\alpha-$ granules are able to efficiently mediate their biological functions when they contain so many proteins with opposing functions (Italiano et al., 2008; Blair and Flaumenhaft, 2009). One possibility is that there are different $\alpha$-granule subpopulations that store distinct cargo. However, the number of discrete types of $\alpha$-granule is not known. Evidence that $\alpha$-granules are heterogeneous comes from several sources. Immunofluorescence microscopy demonstrated that the two $\alpha$-granule cargos von Willebrand factor and fibrinogen do not localize to the same granule (Sehgal and Storrie, 2007). Subsequent studies showed that angiogenic factors localize to distinct compartments and were differentially released by different agonists (Italiano et al., 2008). The molecular mechanisms that mediate differential release are unclear. Differential distribution of SNAREs among subpopulations of $\alpha$-granules may account for differential release. For example, Peters et al. (2012) showed that a population of granules containing vesicle-associated membrane protein-7 (VAMP-7) physically separated from VAMP-3 and VAMP-8-containing granules during spreading. However, the idea of $\alpha$-granule heterogeneity remains controversial and some investigators in the field believe that granule cargos are stochastically distributed and that differential release either does not occur or is controlled at the level of pore expansion.

Granule heterogeneity and differential release have also been evaluated in chromaffin cells. Morphologic studies demonstrate heterogeneity among both LDCVs and synaptic-like microvesicles (SLMVs) (Koval et al., 2001). Studies using carbon-fiber amperometry to measure catecholamine release from individual granules indicated distinct granule populations on the basis of release kinetics (Tang et al., 2005). Different SNAREs and SNARE chaperones may associate with different granule populations and facilitate differential release. For example, different synaptotagmin isoforms associated with LDCVs and SLMVs and this observation could account for their differential secretion in response to calcium (Matsuoka et al., 2011). Other factors influencing chromaffin granule release include pore expansion kinetics and degree. Basal levels of catecholamine release may occur through a restricted fusion pore, while in response to excitation dynamin and myosinmediated mechanisms may elicit fusion pore expansion (Chan et al., 2010). In addition, large aggregates of chromogranin A require complete fusion to facilitate release (Perrais et al., 2004; Felmy, 2007).

Table 1 | Comparison of platelets and chromaffin cells.

\begin{tabular}{|c|c|c|}
\hline & Platelets & Chromaffin cells \\
\hline Distribution & Intravascular & Adrenal medulla \\
\hline Size & $2-3 \mu \mathrm{m}$ & $\sim 20 \mu \mathrm{m}$ \\
\hline \multirow[t]{5}{*}{ Functions } & Hemostasis/thrombosis & Blood pressure modulation \\
\hline & Inflammation & Paracrine signaling \\
\hline & Angiogenesis & Anti-microbial host defense \\
\hline & Anti-microbial host defense & Immune regulation \\
\hline & Mitogenesis & Analgesia \\
\hline Granule types & $\alpha$-Granules, dense granules, and lysosomes & Large dense-core vesicles (LDCVs) and synaptic-like microvesicles (SLMVs) \\
\hline
\end{tabular}


Table 2 | Comparison of granule types contained in platelets and chromaffin cells.

\begin{tabular}{|c|c|c|c|}
\hline & $\alpha$-Granules & Dense granules & LDCVs \\
\hline Diameter & $200-500 \mathrm{~nm}$ & $150 \mathrm{~nm}$ & $150-300 \mathrm{~nm}$ \\
\hline Percentage of cell volume & 10 & $\sim 1$ & 13.5 \\
\hline Contents & 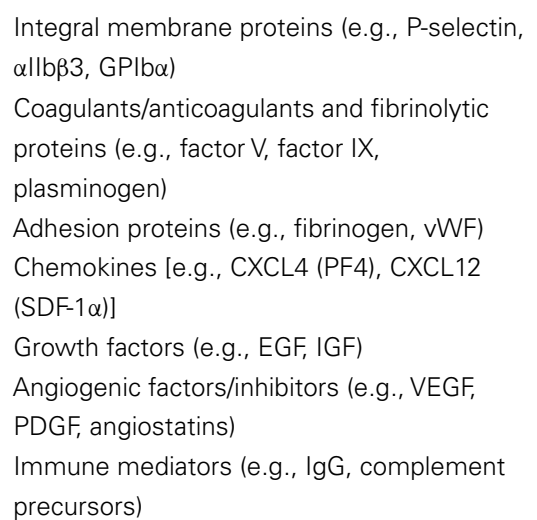 & $\begin{array}{l}\text { Cations (e.g., } \mathrm{Ca}^{2+}, \mathrm{Mg}^{2+} \text { ) } \\
\text { Polyphosphates } \\
\text { Bioactive amines (e.g., } \\
\text { serotonin, histamine) } \\
\text { Nucleotides (e.g., ADP, ATP) }\end{array}$ & $\begin{array}{l}\text { Structural proteins (e.g., granins, } \\
\text { glycoproteins) } \\
\text { Vasoregulators (e.g., catecholamines, } \\
\text { vasostatins, renin-angiotensin) } \\
\text { Paracrine signaling factors (e.g., guanylin, } \\
\text { neurotensin, chromogranin B) } \\
\text { Immune mediators (e.g., enkelytin, } \\
\text { ubiquitin) } \\
\text { Opioids (e.g., enkephalins, endorphins) } \\
\text { lons (e.g., } \mathrm{Ca}^{2+}, \mathrm{Na}^{+}, \mathrm{Cl}^{-} \text {) } \\
\text { Nucleotides (e.g., AMP, GDP, UTP) } \\
\text { Nucleotides } \\
\text { Polyphosphates }\end{array}$ \\
\hline
\end{tabular}

\section{DENSE GRANULES}

Dense granules are a subtype of lysosome-related organelle (LRO). There are 3-6 dense granules/platelet (Flaumenhaft, 2013). These granules are so electron dense that they can be detected by whole mount electron microscopy in the absence of staining. They are highly osmophilic when viewed by TEM. Dense granules play a critical role in hemostasis and thrombosis, releasing factors such as ADP and epinephrine that act in an autocrine and paracrine manner to stimulate platelets at sites of vascular injury. Dense granules also contain factors that are vasoconstrictive such as serotonin (Flaumenhaft, 2013).

Dense granules and LDCVs have been compared based on their unusually high concentrations of cations, polyphosphates, adenine nucleotides, and bioactive amines such as serotonin and histamine (Sigel and Corfu, 1996) (Figure 2; Table 2). In platelets, adenine nucleotides are concentrated at $\sim 653 \mathrm{mM}$ ADP and $\sim 436 \mathrm{mM}$ ATP (Holmsen and Weiss, 1979). Calcium is at 2.2 M. Chromaffin granules and platelet dense granules are among the few mammalian granule types to contain polyphosphates (Aikawa et al., 1971; Ruiz et al., 2004). Active transport mechanisms are thought to contribute to efficient concentration of these constituents in platelets (Figure 2). A vesicular $\mathrm{H}^{+}$-ATPase proton pump maintains the dense-granule lumen at $\mathrm{pH} \sim 5.4$ (Dean et al., 1984), similar to the $\mathrm{pH}$ of LDCVs. The multidrug transporter MRP4, a multidrug resistance protein, is found on platelet dense granules and is proposed to transport adenine nucleotides into these granules (Jedlitschky et al., 2004). Uptake of serotonin from platelet cytosol into dense granules is mediated by vesicular monoamine transporter 2 (VMAT2). Transport is driven by an electrochemical proton gradient across the granule membrane. VMAT2 also appears to mediate histamine transport into dense granules (Fukami et al., 1984). The primary nucleotide transporter in chromaffin cells is Slc17A/VNUT (Sawada et al., 2008). Whether or not platelets use Slc17 family transporters to concentrate dense-granule cargo has yet to be evaluated. Like platelets, chromaffin cells use VMAT2, in addition to VMAT1, to pump monoamines from the cytosol into their granules.

\section{LYSOSOMES}

Platelets contain few primary and secondary lysosomes. These lysosomes contain many acid hydrolases and cathepsins as cargo and express CD63 and LAMP-2 in their membrane. Platelet lysosome function is not well-studied. They may serve a role in endosomal digestion, as observed in nucleated cells (Flaumenhaft, 2013).

\section{AN OVERVIEW OF PLATELET GRANULE RELEASE}

Platelets are uniform discoid cells that circulate in a quiescent state and undergo a dramatic morphological change when activated. Their plasma membrane surface area is $\sim 19 \mu \mathrm{m}^{2}$ and the total surface area of their granules is $\sim 14 \mu \mathrm{m}^{2}$. They have an unusual membrane system, including an open canalicular system (OCS), which is a system of tunneling invaginations of the plasma membrane that is unique to platelets and is estimated to have a surface area of $\sim 14 \mu \mathrm{m}^{2}$ (Flaumenhaft, 2013). The OCS tracks through the platelet, but is topologically similar to the plasma membrane in that it possesses both an extracellular and a cytosolic face. Platelets also have a dense tubular system (DTS), which is a membrane system thought to be derived from the megakaryocytic endoplasmic reticulum. The DTS serves as an intracellular calcium storage site, but is not directly connected to either the plasma membrane or the OCS (van Nispen tot Pannerden et al., 2010).

Ultrastructural studies have demonstrated several atypical features of the platelet release reaction. In the resting state, platelet $\alpha$-granules and dense granules are distributed throughout the platelet. With activation-induced shape change, granules become localized in a central granulomere. As with chromaffin granules, platelet granules may fuse with one another in a process termed 


\section{A Platelet Dense Granule}

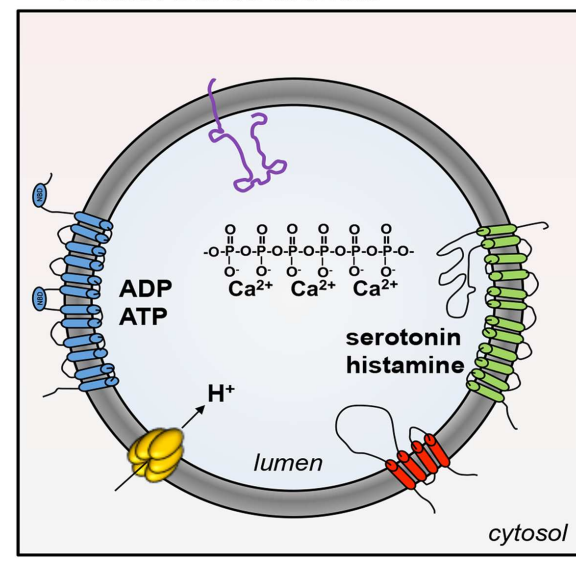

FIGURE 2 | A comparison of platelet dense granules and chromaffin LDCVs. (A) Several membrane pumps concentration granule contents in the maturing granule. VMAT2 concentrates serotonin (green). An $\mathrm{H}^{+}$-ATPase proton pump maintains the granule at $\mathrm{pH} \sim 5.4$ (yellow). MRP4 (b/ue) is thought to concentrate adenine nucleotides into dense granules. Dense granules also express the tetraspanin CD63 (red) and the lysosomal marker LAMP-2 (purple). Dense granules contain a core of calcium chelated by polyphosphate. (B) The chromaffin large dense-core vesicle (LDCV) express a
B Large Dense Core Vesicle

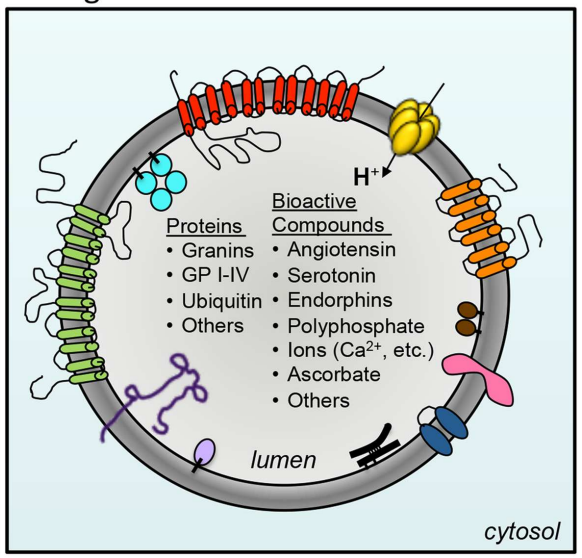

homotypic fusion (Ginsberg et al., 1980). However, during exocytosis platelet granules then fuse with the OCS (Stenberg et al., 1984; Escolar and White, 1991). Granule contents are released into the OCS and diffuse out into the extracellular environment (Escolar and White, 1991). Exocytosis via fusion directly with plasmalemma has also been described (Morgenstern et al., 1987). SNAREs are localized on platelet membranes in a manner to support fusion of granules with OCS, plasma membrane, or other granules (Feng et al., 2002). Despite the morphological differences between exocytosis in platelets and chromaffin cells, similarities in the release mechanism have enabled platelet biologists to use chromaffin cells as a model in studying platelet granule release. For example, both platelets and chromaffin cells require $\mathrm{Ca}^{2+}$ influx as a mediator of exocytosis via different mechanisms. Upon platelet activation by agonists, the concentration of cytosolic $\mathrm{Ca}^{2+}$ increases activating protein kinase $\mathrm{c}(\mathrm{PKC})$, which is important for granule secretion (Knight et al., 1988; Flaumenhaft, 2013). Formation of an action potential in chromaffin cells triggers $\mathrm{Ca}^{2+}$ influx via $\mathrm{Ca}^{2+}$ channels thereby triggering exocytosis (Knight and Scrutton, 1980; Knight et al., 1982; Knight and Baker, 1985; Penner and Nicher, 1988; Cheek and Barry, 1993; Livett, 1993; Aunis, 1998; Garcia et al., 2006).

\section{THE CYTOSKELETAL AS BOTH BARRIER AND FACILITATOR IN EXOCYTOSIS}

The observation that platelet granule secretion occurs concurrently with a dramatic change in the shape of the platelet has prompted investigators to evaluate the role of the cytoskeleton in granule release. Platelets are rich in actin, which is the most abundant platelet protein. The resting platelet contains $40 \%$ filamentous actin (F-actin). Upon platelet activation, the percentage of F-actin increases to $80 \%$. Studies using cytochalasins (CoX, variety of membrane proteins including VMAT1 amine transporter (red), $\mathrm{H}^{+}$-ATPase (yellow), Cytochrome b561 (orange), p65 (pink), peptidyl $\alpha$-amidation monooxygenase (PAM) (blue), LAMP-1 (dark purple), and VNUT/SIc17a nucleotide carrier (green). In addition, the following peripheral proteins are associated with the LDCV membrane: endopeptidases PC1/PC2 (brown), GPIII/SGP2/clusterin (black), carboxypeptidase $\mathrm{H}$ (lavender), and Dopamine $\beta$-hydroxylase ( $\mathrm{D} \beta \mathrm{H}$ ) (turquoise). The LDCV core contains a large number of different proteins and bioactive compounds.

1988), latrunculin A (Flaumenhaft et al., 2005), $\mathrm{Ca}^{2+}$-mediated stimulation of the F-actin severing protein scinderin (Marcu et al., 1996), and PKC-mediated stimulation of MARCKS (Trifaro et al., 2002) demonstrate increased dense-granule release with inhibition of actin polymerization or with cleavage of F-actin. Inhibition of actin polymerization also augments the kinetics and degree of $\alpha$-granule release (Flaumenhaft et al., 2005). These results suggest that F-actin disassembly might actually be required for normal granule secretion and that activation-mediated granule release is related to actin.

In contrast to the barrier function that the cytoskeleton serves in the resting state, de novo actin polymerization during platelet activation contributes to granule release as evidenced by the observation that high concentrations of inhibitors of actin polymerization block $\alpha$-granule release (Woronowicz et al., 2010). These studies led to speculation that an actin barrier helps prevent inappropriate $\alpha$-granule exocytosis, but that some de novo actin polymerization is required for $\alpha$-granule release. Woronowicz et al. (2010) demonstrated that the target membrane SNARE (t-SNARE) SNAP-23 associates with the actin cytoskeleton of resting and activated platelets. In a cell-free platelet granule secretory system, inhibition of F-actin formation blocks release of SNARE-dependent $\alpha$-granule contents, whereas actin polymerization stimulates $\alpha$ granule release (Woronowicz et al., 2010). Yet the molecular mechanism by which the binding of SNAREs to the platelet cytoskeleton facilitates granule release is unknown. Overall, actin polymerization appears to serve a bipartite role in platelet granule secretion, both as a barrier to prevent inadvertent loss of thrombogenic cargo and as a facilitator of secretion.

Actin has been shown to serve a barrier function in chromaffin cells. The most well-studied pathways for disrupting the cortical Factin barrier during chromaffin exocytosis include $\mathrm{Ca}^{2+}$-mediated 
stimulation of scinderin and PKC-mediated stimulation of MARCKS (Trifaro et al., 2002). Scinderin also potentiates $\mathrm{Ca}^{2+}$-induced granule secretion in a permeabilized platelet system and inhibitory peptides directed at scinderin inhibited granule release in this same assay (Marcu et al., 1996). MARCKS-derived inhibitory peptides blocks phorbol ester-induced platelet granule release, invoking MARCKS phosphorylation and deactivation in facilitating the disruption of F-actin required for granule release (Elzagallaai et al., 2000, 2001).

\section{SNARE FUNCTION IN PLATELET AND CHROMAFFIN GRANULE EXOCYTOSIS}

Soluble NSF attachment protein receptors, or SNAREs, assemble into complexes to form a universal membrane fusion apparatus (Jahn and Scheller, 2006). Although all cells use SNAREs for membrane fusion, different cells possess different SNARE isoforms. Neurons and neuroendocrine cells use a set of SNAREs that is distinct from those used in non-neuronal cells. In contrast, platelets and chromaffin cells use many of the same chaperone proteins to regulate SNARE-mediated secretion (Table 3 ).

VAMP-8 (endobrevin) is the primary and most abundant vesicular SNARE (v-SNARE) in platelets (Ren et al., 2007; Graham et al., 2009). It is required for activation-induced release of $\alpha$ granules, dense granules, and lysosomes (Ren et al., 2007) as evidenced by studies using permeabilized human platelets exposed to anti-VAMP-8 antibodies and by evaluation of secretion from VAMP- $8^{-1-}$ platelets (Ren et al., 2007). Platelet-mediated thrombus formation relies on ADP and other factors released from platelet granules. VAMP- $8^{-1-}$ mice demonstrate decreased thrombus formation upon vascular injury (Graham et al., 2009). Electron microscopy indicates that platelet VAMPs localize primarily to granule membranes (Feng et al., 2002). VAMP-2, -3, -5, and 7 are also present in platelets. VAMPs 2 and 3 mediate granule release in VAMP-8 deficiency (Ren et al., 2007). VAMP-7 contains a profilin-like longin domain, has been shown to function in neurite extension, and associates with $\mathrm{F}$-actin during cell spreading (Alberts et al., 2006). Granules expressing VAMP-7 move to the periphery of the platelet during spreading and may represent a distinct granule type that functions to provide membrane to cover growing cytoskeletal structures following activation (Peters et al., 2012). Future studies will evaluate the respective roles of VAMP-8 and VAMP-7 in mediating granule release during spreading and identify the participating membrane compartments.

Synaptosomal-associated protein 23 (SNAP-23), a t-SNARE, is required for release from all three types of granules in platelets (Chen et al., 2000; Lemons et al., 2000). Nearly 2/3rds of SNAP-23 associates with the platelet plasma membrane, with the remaining SNAP-23 distributed between the granule membrane and membranes of the OCS (Feng et al., 2002). SNAP-23 contains five palmitoylation sites in its membrane-binding domain. Cleavage of palmitate by acyl-protein thioesterase 1 releases SNAP- 23 from platelet membranes demonstrating that SNAP-23 associates with membranes via these palmitoylation sites (Sim et al., 2007). In addition, SNAP-23 associates with the actin cytoskeleton in both resting and activated platelets (Woronowicz et al., 2010). Antibodies to SNAP-23 or addition of an inhibitory C-terminal peptide against SNAP-23 both block dense-granule release in human
Table 3 | SNAREs and SM proteins in platelets and chromaffin cells.

\begin{tabular}{|c|c|c|}
\hline & Platelets & Chromaffin cells \\
\hline \multirow[t]{6}{*}{ v-SNARES } & Vamp-2 & VAMP-2 \\
\hline & Vamp-3 & VAMP-3 \\
\hline & Vamp-4 & VAMP-7 (TI-VAMP) \\
\hline & Vamp-5 & \\
\hline & Vamp-7 (TI-VAMP) & \\
\hline & Vamp-8 & \\
\hline \multirow[t]{10}{*}{ t-SNARES } & SNAP-23 & SNAP-23 \\
\hline & SNAP-25 & SNAP-25a \\
\hline & SNAP-29 & SNAP-25b \\
\hline & Syntaxin-1 & Syntaxin-1A \\
\hline & Syntaxin-2 & Syntaxin-1B \\
\hline & Syntaxin-4 & Syntaxin-2 \\
\hline & Syntaxin-7 & Syntaxin-3 \\
\hline & Syntaxin-8 & Syntaxin-4 \\
\hline & Syntaxin-11 & \\
\hline & Syntaxin-12 & \\
\hline \multirow[t]{2}{*}{ Munc13 family } & Munc13-4 & Munc13-1 \\
\hline & & Munc13-4 \\
\hline \multirow[t]{3}{*}{ Munc18 family } & Munc18-1 & Munc18-1 \\
\hline & Munc18-2 & Munc18-2 \\
\hline & Munc18-3 & Munc18-3 \\
\hline
\end{tabular}

Essential components of the secretory machinery are highlighted.

Criteria: platelets: Vamp-8, murine knockout; SNAP-23, inhibitory antibodies, inhibitory peptides, overexpression of dominant negative construct; syntaxin-11, FLH4; Munc13-4, murine knockout, FLH3; Munc18-2, FLH5.

Chromaffin: VAMP-2, neurotoxin cleavage; SNAP-25, deletion of $C$ terminus; Syntaxin 1, botulinum neurotoxin $C 1$ and inhibitory antibodies; Munc18-1, murine knockout.

platelets (Chen et al., 2000). In addition, overexpression of dominant negative SNAP-23 inhibits dense-granule release in murine platelets (Gillitzer et al., 2008).

Our understanding of the role of syntaxins, another family of tSNAREs, in platelet granule release has recently evolved. Platelets express syntaxin-2, $-4,-7,-8,-11$, and -12 . Whiteheart's group identified a patient with Familial Hemophagocytic Lymphohistiocytosis type four (FHL-4) who was deficient in syntaxin-11 and exhibited a significant granule secretion defect. An inhibitory antibody that this group had previously used to demonstrate a role for syntaxin-2 in granule release was found to cross-react with syntaxin-11, further suggesting a role for syntaxin-11 in platelet exocytosis (Ye et al., 2012). They also demonstrated that syntaxin$2^{-I-}$ mice, syntaxin $-4^{-1-}$ mice, and double knockout mice all demonstrated normal granule release. On the basis of these results, syntaxin-11 appears to be the primary syntaxin involved in platelet granule release.

In chromaffin cells, VAMP-2 is the primary v-SNARE and is required for efficient, rapid release of granule constituents in response to agonists (Table 3). Proteolytic cleavage of VAMP-2 by botulinum neurotoxins $A$ through $G$ or tetanus neurotoxin results in decreased DCV secretion in chromaffin cells (Knight 
et al., 1985; Schiavo et al., 1992; Xu et al., 1998). VAMP-3 is less efficient than and plays a subordinate role to VAMP-2, only functioning in its absence (Borisovska et al., 2005). VAMP-7 serves a central role in neurite outgrowth in chromaffin-like cells (Coco et al., 1999; Martinez-Arca et al., 2000, 2001), analogous to its putative role in providing membrane for platelet spreading (Peters et al., 2012). Studies in PC12 cells indicate that the NH2-terminal domain of VAMP-7 negatively regulates neurite outgrowth since neurite outgrowth is blocked by overexpression of this domain and enhanced by its deletion (Martinez-Arca et al., 2000, 2001). SNAP25a has established roles in both docking and priming of DCVs and participates in agonist-dependent fusion of secretory vesicles in complex with both VAMP-2 and syntaxin-1A. Deletion of the C-terminal synaptotagmin-interacting residues of SNAP-25 in PC12 cells results in decreased DCV secretion (Zhang et al., 2002). Adrenal chromaffin cells express syntaxins-1A, $-1 \mathrm{~B},-2,-3$, and -4 . Viral infection with botulinum neurotoxin $\mathrm{C} 1$ cleaves syntaxin$1 \mathrm{~A}, 1 \mathrm{~B}, 2$, and 3 resulting in reduced DCV docking at the plasma membrane (de Wit et al., 2006) and an inhibitory antibody to syntaxin-1 decreases catecholamine release in bovine chromaffin cells (Gutierrez et al., 1995).

\section{SNARE CHAPERONE FUNCTION IN PLATELET AND CHROMAFFIN GRANULE EXOCYTOSIS}

Although not members of the exocytic core complex, another important group of proteins involved in degranulation in secretory cells are the Sec1/Munc18-like (SM) proteins which function as SNARE chaperones (Carr and Rizo, 2010). Platelets and chromaffin cells possess a similar repertoire of SM proteins, including members of the Munc13 and Munc18 families. These proteins are SNARE regulators that have no apparent membrane-binding domain, but bind syntaxin upon phosphorylation by PKC (Houng et al., 2003; Schraw et al., 2003) and interact with the regulatory $\mathrm{N}$-terminal sequence of syntaxins (Ashery et al., 2000; Rosenmund et al., 2002). Munc13 family members include Muncs13-1, -2, -3, and 4 . These proteins have two $\mathrm{C} 2\left(\mathrm{Ca}^{2+}\right.$-binding $)$ and one $\mathrm{C} 1$ (DAG/phorbol ester-binding) domains (Figure 3). They interact with SNARE proteins via two Munc13 (mammalian) homology domains, MHDs 1 and 2 (Guan et al., 2008), which are involved in dissociating Munc18 protein/syntaxin interactions (Sassa et al., 1999), thereby promoting trans SNARE complex assembly.

Munc13-4 is the only Munc13 family member found in platelets. It lacks the N-terminal C1 domain present in Munc13-1, -2 , and -3 and the MHD2 domain present in the other Munc13 family members, but has a central MHD1 domain and binds directly to syntaxins in platelets via interaction with the syntaxin H3 domain (Boswell et al., 2012). It is ubiquitously expressed, but enriched in cells of the hematopoietic lineage (Song et al., 1998; Feldmann et al., 2003). In platelets, the Munc13-4 interaction with activated Rab27a/b is important for SNARE binding (via MHD1 interaction), granule formation and plasma membrane interaction (Figure 3) (Song et al., 1998; Shirakawa et al., 2004; Ishii et al., 2005; Boswell et al., 2012). Boswell et al. (2012) determined that the C2A domain of Munc13-4 is required for $\mathrm{Ca}^{2+}$-dependent SNARE interaction, whereas the $\mathrm{C} 2 \mathrm{~B}$ domain mediates $\mathrm{Ca}^{2+}$. dependent membrane association. Mutation of Munc13-4 results in another form of familial hemophagocytic lymphohistiocytosis (FHL3) (Feldmann et al., 2003) and Munc13-4 deletion from murine platelets results in complete ablation of dense-granule release and impaired release from $\alpha$-granules in vitro indicating its importance in $\mathrm{Ca}^{2+}$ regulation of SNARE interactions with the plasma membrane (Ren et al., 2010).

Munc13-4 is a rate-limiting protein for granule exocytosis in both platelets and chromaffin cells. As with platelet granule release, Munc13-4 triggers rapid and efficient release of catecholamines from chromaffin-like PC12 cells (Boswell et al., 2012). Munc13-4 promotes trans-exocytic core complex formation in a $\mathrm{Ca}^{2+}$-dependent manner in both chromaffin cells and platelets. In addition to Munc13-4, Munc13-1 serves a role in DCV secretion in chromaffin cells. Overexpression of Munc13-1 results in increased DCV secretion (Ashery et al., 2000; Stevens et al., 2005) and its interaction with syntaxin-1 is important for DCV priming (Stevens et al., 2005).

Platelets express three Munc18 isoforms: Munc18-1, 18-2 and 18-3. All three isoforms are associated with granule and OCS membranes in resting platelets (Schraw et al., 2003). Al Hawas et al. (2012) recently demonstrated that defects in the Munc18-2 gene result in familial hemophagocytic lymphohistiocytosis type

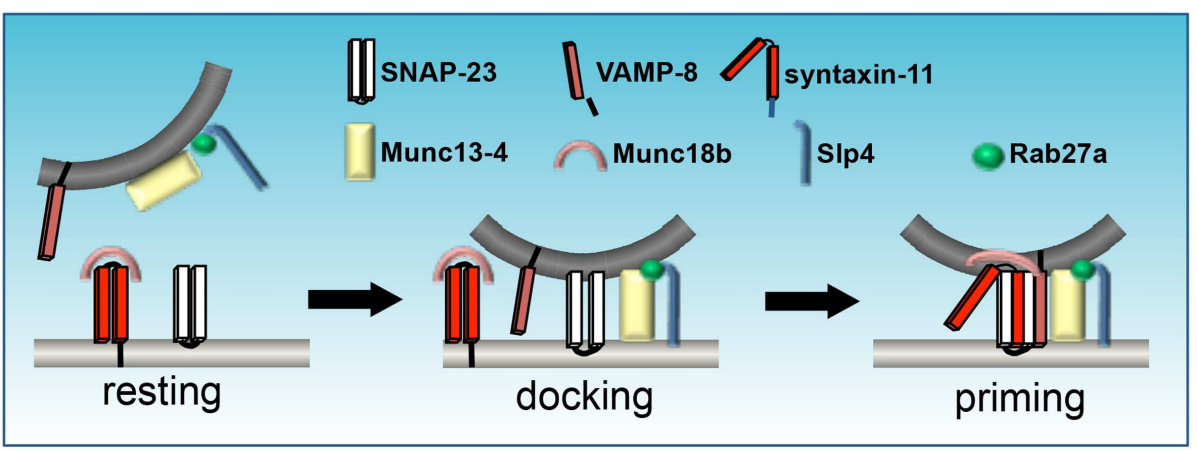

FIGURE 3 | Assemblage of SNAREs and SM proteins during platelet granule exocytosis. Munc18b sequesters syntaxin in an inactive state. Munc13-4 docks opposing membranes via interactions with Rab27a, which also binds SIp1. Activation promotes a conformational change in Munc18b that enables the coiled-coil domain of syntaxin to form a four-helical bundle with SNAP-23 and VAMP. Mutations in Munc13-4, as in familial hemophagocytic lymphohistiocytosis (FHL)-3, syntaxin-11 (FHL-4), Munc18b (FHL-5), or Rab27a (Griscelli syndrome) result in defective secretion (figure adapted from Flaumenhaft, 2013). 
5 (FHL5). These patients demonstrate decreased $\alpha$ - and densegranule secretion and levels of both Munc18-2 and syntaxin11 were diminished, indicating that Munc18-2 plays a key role in platelet exocytosis and, potentially, a regulatory role toward syntaxin-11.

In chromaffin cells, Munc18-1 participates in granule docking/priming and SNARE engagement via its interaction with syntaxin 1 (Hata et al., 1993; Pevsner et al., 1994). Munc18-1 knock out in embryonic cells results in decreased DCV docking at the plasma membrane (Voets et al., 2001; Gulyas-Kovacs et al., 2007). In addition, syntaxin 1 expression is decreased by $50 \%$ in Munc18-1 deficient neurons and chromaffin cells (Voets et al., 2001; Gulyas-Kovacs et al., 2007). Munc18-1 interaction with the "closed" conformation of syntaxin 1 appears to be important for docking of the secretory vesicle at the plasma membrane (Dulubova et al., 1999; Yang et al., 2000; Schutz et al., 2005; Gulyas-Kovacs et al., 2007). However, Munc18-1 interactions with the N-terminal peptide of syntaxin-1 (in the "open" conformation) is required for membrane fusion to occur (Khvotchev et al., 2007; Gerber et al., 2008; Rathore et al., 2010), indicating that Munc18-1 is important in both early and late stages of exocytosis. Munc18-2 also shows affinity for syntaxins$1,-2$, and -3 in chromaffin cells. While Munc18-2 rescued the reduced docking phenotype in Munc18-1 $1^{-1-}$ animals, they continued to exhibit impaired vesicle priming (Gulyas-Kovacs et al., 2007). Munc18-3 is ubiquitously expressed and has been implicated in secretion in chromaffin cells. However, Munc18-3 only partially rescued the Munc18-1 $-1-$ secretion defect in chromaffin cells and deletion of Munc18-3 from chromaffin cells did not cause defects in granule secretion (Gulyas-Kovacs et al., 2007).

\section{THE PLATELET FUSION PORE}

Although there are many methods to evaluate platelet granule release, platelet secretion assays are largely restricted to bulk assays of cargo release (e.g., ADP, serotonin, platelet factor 4) or granule membrane receptor surface expression (e.g., P-selectin, CD63). These assays are inadequate for evaluation of the release of single granules and unable to detect membrane fusion events that occur in the millisecond time frame. Standard electrophysiology using patch-clamp techniques are difficult to apply to the platelet because of their small size and atypical membrane system. More recently, however, platelet investigators are applying some of the same approaches used to evaluate fusion pore dynamics in chromaffin cells. In particular, investigators are using single-cell amperometry to evaluate the release kinetics of single granules from platelets. Carbon-fiber microelectrode amperometry is being used to detect serotonin release from platelets stimulated with thrombin (Ge et al., 2008, 2009, 2010). Tracings indicate previously unrecognized fusion events such as "kiss and run" fusion and foot process formation (Wightman and Haynes, 2004) (Figure 4). This approach has enabled an appreciation of nuances of membrane fusion in platelets that have previously gone unrecognized and, more importantly, have enabled investigators to begin to evaluate the molecular mechanisms of pore formation in platelets. Amperometry has recently been used to evaluate the role of dynamin family proteins in platelet and chromaffin cell granule release.

Dynamins are a family of large GTPases that act as mechanoenzymes, demonstrating both oligomerization-dependent GTPase and membrane modeling activities (Piersma et al., 2009). Although originally described as mediators of membrane scission during vesicle endocytosis (Graham et al., 2004; Wegrzyn et al., 2010), dynamin GTPases are now recognized to function in exocytosis (Graham et al., 2002; Tsuboi et al., 2004; Fulop et al., 2008; Anantharam et al., 2010, 2011; Gonzalez-Jamett et al., 2010). In particular, dynamins act immediately upon membrane fusion to regulate the release of granule content. Dynamin and dynamin-related proteins are found in platelets. Dynamin 3 is upregulated during megakaryopoiesis (Reems et al., 2008; Gieger et al., 2011; Wang et al., 2011). Dynamin 2 and dynamin-related protein 1 (Drp1) are present in platelets, but dynamin 1 is not.

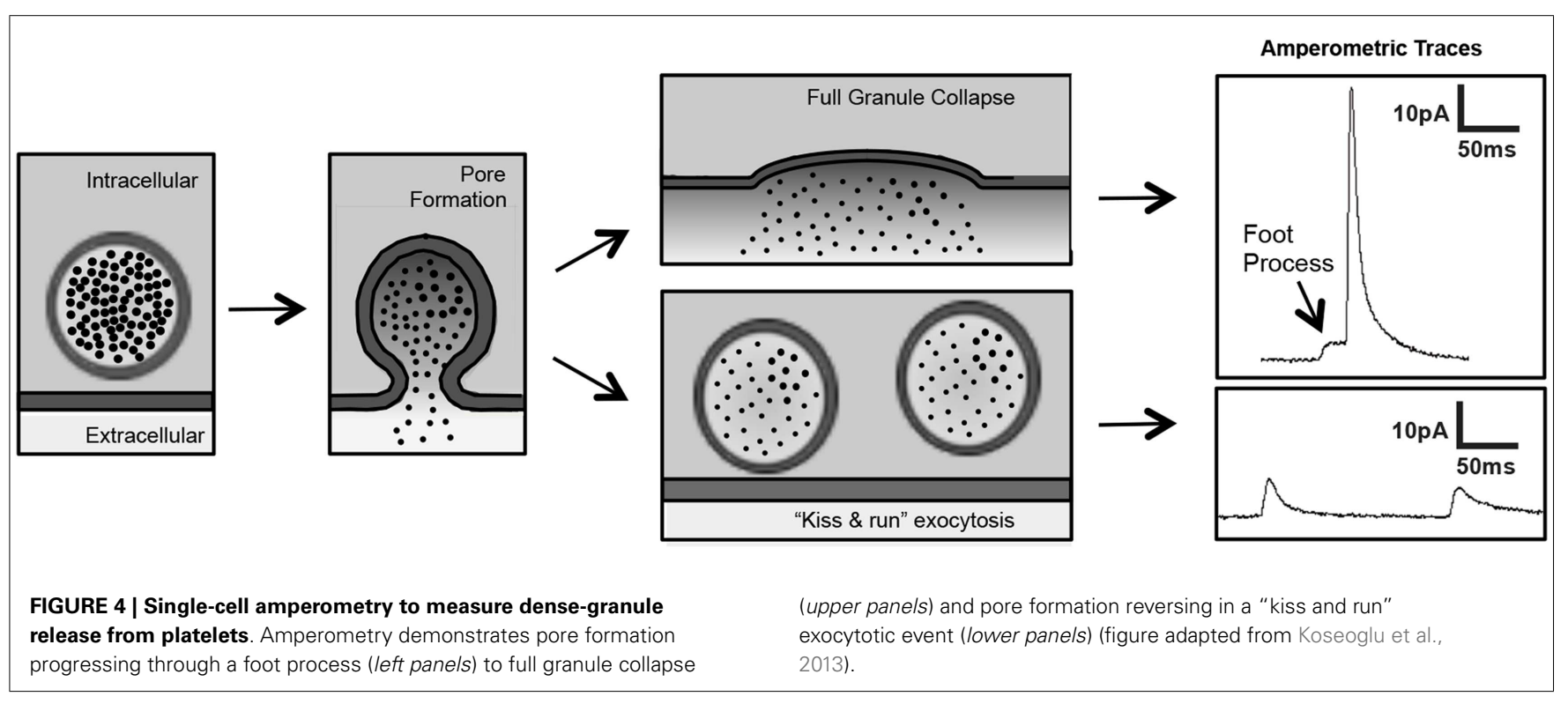


Drp1 is phosphorylated upon platelet activation (Koseoglu et al., 2013). Inhibition of platelets using dynasore or MiTMAB, which inhibit the activity of dynamin family proteins, block agonistinduced platelet granule secretion (Koseoglu et al., 2013). The Drp1 inhibitor, mdivi-1, also blocks platelet granule exocytosis. Studies using single-cell amperometry demonstrate that mdivi1 exposure results in fusion pore instability as evidenced by decreased foot process formation and inefficient pore expansion as evidenced by an increased $\mathrm{T}_{1 / 2}$ (Koseoglu et al., 2013). These observations implicate dynamin and dynamin-related proteins in platelet fusion pore dynamics. However, the mechanism by which Drp1, which is typically associated with mitochondrial fission, impacts platelet granule release remains to be determined.

Dynamin-mediated pore expansion in chromaffin has been evaluated using total internal reflection fluorescence microscopy and amperometry. In chromaffin cells overexpressing a dynamin I mutant with low GTPase activity, deformations in the membrane associated with fusion are long-lived, indicating defective pore expansion (Anantharam et al., 2011). Chromaffin cells overexpressing a dynamin I mutant with enhanced GTPase activity demonstrate increased pore expansion. These observations have led to a model in which dynamin restricts fusion pore expansion until GTPase activity is stimulated. The higher the GTPase activity, the faster the expansion of the fusion pore (Gerber et al., 2008). Dynamins appear to associate with actin, SNAREs, and synaptotagmin family proteins to participate in fusion pore expansion (Chan et al., 2010; Gu et al., 2010; Anantharam et al., 2012). However, the importance of these associations is poorly understood.

\section{REFERENCES}

Aikawa, M., Schoenbechler, M. J., Barbaro, J. F., and Sadun, E. H. (1971). Interaction of rabbit platelets and leukocytes in the release of histamine. Electron microscopic observations. Am. J. Pathol. 63, 85-98.

Al Hawas, R., Ren, Q., Ye, S., Karim, Z. A., Filipovich, A. H., and Whiteheart, S. W. (2012). Munc18b/STXBP2 is required for platelet secretion. Blood 120, 2493-2500. doi:10.1182/blood2012-05-430629

Alberts, P., Rudge, R., Irinopoulou, T., Danglot, L., Gauthier-Rouvière, C., and Galli, T. (2006). Cdc42 and actin control polarized expression of TI-VAMP vesicles to neuronal growth cones and their fusion with the plasma membrane. Mol. Biol. Cell 17, 1194-1203. doi:10.1091/mbc.E05-07-0643

Anantharam, A., Axelrod, D., and Holz, R. W. (2012). Polarized TIRFM reveals changes in plasma membrane topology before and during granule fusion. Cell. Mol. Neurobiol. 30, 1343-1349. doi:10.1007/s10571010-9590-0

Anantharam, A., Bittner, M. A., Aikman, R. L., Stuenkel, E. L.,
Schmid, S. L., Axelrod, D., et al. (2011). A new role for the dynamin GTPase in the regulation of fusion pore expansion. Mol. Biol. Cell 22, 1907-1918. doi:10.1091/ mbc.E11-02-0101

Anantharam, A., Onoa, B., Edwards, R. H., Holz, R. W., and Axelrod, D. (2010). Localized topological changes of the plasma membrane upon exocytosis visualized by polarized TIRFM. J. Cell Biol. 188, 415-428. doi:10.1083/jcb.200908010

Ashery, U., Varoqueaux, F., Voets, T., Betz, A., Thakur, P., Koch, H., et al. (2000). Munc13-1 acts as a priming factor for large dense-core vesicles in bovine chromaffin cells. EMBO J. 19, 3586-3596. doi:10.1093/emboj/ 19.14.3586

Aunis, D. (1998). Exocytosis in chromaffin cells of the adrenal medulla. Int. Rev. Cytol. 181, 213-320. doi:10.1016/ S0074-7696(08)60419-2

Blair, P., and Flaumenhaft, R. (2009). Platelet alpha-granules: basic biology and clinical correlates. Blood Rev. 23, 177-189. doi:10.1016/j.blre.2009.04.001

\section{CONCLUSION}

Some characteristics of regulated secretion shared between platelets and chromaffin cells are common to all secretory systems. However, these secretory systems also share some unusual features that, if not unique to these cells, are not universally observed among secretory systems. These special commonalities may provide avenues for researchers investigating these cells types to further define these secretory systems. For example, the unusual density of LDCVs and platelet dense granules and their ability to concentrate nucleotides, bioactive amines, and polyphosphates raises the possibility that may use similar transporters. Some similarities in transporters such as VMAT2 have already been described. Further probing could reveal further overlap (e.g., Scl17A transporters in platelet dense granules, multidrug resistance transporters in chromaffin cells, or yet undiscovered transporters that are common to both cells). The ability of chromaffinlike PC12 cells to use VAMP-7 for neurite outgrowth and platelets to use VAMP-7 during spreading speaks to potential underlying similarities between the molecular mechanisms of membrane utilization during shape change. The role of dynamin family proteins in exocytosis is an emerging area of interest in secretion biology and further studies of these two cell types may reveal how they use these mechanoenzymes to regulate fusion pore formation during exocytosis. Historically, the study of the chromaffin cell has advanced more quickly than that of the platelet and has helped direct how platelet biologists have approached the study of granule exocytosis. As the study of platelet exocytosis progresses, understanding this secretory system may help chromaffin cell biologists better understand elements of granule formation and exocytosis in neuroendocrine cells.

Borisovska, M., Zhao, Y., Tsytsyura, Y., Glyvuk, N., Takamori, S., Matti, U., et al. (2005). v-SNAREs control exocytosis of vesicles from priming to fusion. EMBO J. 24, 2114-2126. doi:10.1038/sj.emboj.7600696

Boswell, K. L., James, D. J., Esquibel, J. M., Bruinsma, S., Shirakawa, R., Horiuchi, H., et al. (2012). Munc134 reconstitutes calcium-dependent SNARE-mediated membrane fusion. J. Cell Biol. 197, 301-312. doi:10.1083/jcb.201109132

Buchanan, G. R., and Handin, R. I. (1976). Platelet function in the Chediak-Higashi syndrome. Blood 47, 941-948.

Carr, C. M., and Rizo, J. (2010). At the junction of SNARE and SM protein function. Curr. Opin. Cell Biol. 22, 488-495. doi:10.1016/j.ceb.2010.04.006

Chan, S. A., Doreian, B., and Smith, C. (2010). Dynamin and myosin regulate differential exocytosis from mouse adrenal chromaffin cells. Cell. Mol. Neurobiol. 30, 1351-1357. doi:10.1007/s10571-010-9591-z

Cheek, T. R., and Barry, V. A. (1993). Stimulus-secretion coupling in excitable cells: a central role for calcium. J. Exp. Biol. 184, 183-196.

Chen, D., Lemons, P. P., Schraw, T., and Whiteheart, S. W. (2000). Molecular mechanisms of platelet exocytosis: role of SNAP-23 and syntaxin 2 and 4 in lysosome release. Blood 96, 1782-1788.

Coco, S., Raposo, G., Martinez, S., Fontaine, J. J., Takamori, S., Zahraoui, A., et al. (1999). Subcellular localization of tetanus neurotoxin-insensitive vesicleassociated membrane protein (VAMP)/VAMP7 in neuronal cells: evidence for a novel membrane compartment. J. Neurosci. 19, 9803-9812.

Coppinger, J. A., Cagney, G., Toomey, S., Kislinger, T., Belton, O., McRedmond, J. P., et al. (2004). Characterization of the proteins released from activated platelets leads to localization of novel platelet proteins in human atherosclerotic lesions. Blood 103, 2096-2104. doi:10.1182/blood2003-08-2804

Costa, J. L., Fauci, A. S., and Wolff, S. M. (1976). A platelet abnormality in the Chediak-Higashi syndrome of man. Blood 48, 517-520. 
Cox, A. C. (1988). Cytochalasin E enhances the protein kinase Cdependent process of secretion. Biochem. Biophys. Res. Commun. 150, 745-751. doi:10.1016/0006291X(88)90454-8

de Wit, H., Cornelisse, L. N., Toonen, R. F., and Verhage, M. (2006). Docking of secretory vesicles is syntaxin dependent. PLoS ONE 1:e126. doi:10.1371/journal.pone.0000126

Dean, G. E., Fishkes, H., Nelson, P. J., and Rudnick, G. (1984). The hydrogen ion-pumping adenosine triphosphatase of platelet dense granule membrane. Differences from F1F0and phosphoenzyme-type ATPases. J. Biol. Chem. 259, 9569-9574.

Dulubova, I., Sugita, S., Hill, S., Hosaka, M., Fernandez, I., Sudhof, T. C., et al. (1999). A conformational switch in syntaxin during exocytosis: role of munc18. EMBO J. 18, 4372-4382. doi:10.1093/emboj/18.16.4372

Elzagallaai, A., Rose, S. D., Brandan, N. C., and Trifaro, J. M. (2001). Myristoylated alanine-rich $\mathrm{C}$ kinase substrate phosphorylation is involved in thrombin-induced serotonin release from platelets. $\mathrm{Br}$. J. Haematol. 112, 593-602. doi:10.1046/j.13652141.2001.02642.x

Elzagallaai, A., Rose, S. D., and Trifaro, J. M. (2000). Platelet secretion induced by phorbol esters stimulation is mediated through phosphorylation of MARCKS: a MARCKS-derived peptide blocks MARCKS phosphorylation and serotonin release without affecting pleckstrin phosphorylation. Blood 95, 894-902.

Escolar, G., and White, J. G. (1991). The platelet open canalicular system: a final common pathway. Blood Cells 17, 467-485. discussion 486-495,

Feldmann, J., Callebaut, I., Raposo, G., Certain, S., Bacq, D., Dumont, C., et al. (2003). Munc13-4 is essential for cytolytic granules fusion and is mutated in a form of familial hemophagocytic lymphohistiocytosis (FHL3). Cell 115, 461-473. doi:10. 1016/S0092-8674(03)00855-9

Felmy, F. (2007). Modulation of cargo release from dense core granules by size and actin network. Traffic 8, 983-997. doi:10.1111/j.16000854.2007.00583.x

Feng, D., Crane, K., Rozenvayn, N., Dvorak, A. M., and Flaumenhaft, R. (2002). Subcellular distribution of 3 functional platelet SNARE proteins: human cellubrevin, SNAP-23, and syntaxin 2. Blood 99, 4006-4014. doi:10.1182/blood.V99.11.4006

Flaumenhaft, R. (2013). "Platelet secretion," in Platelets, 3rd Edn, ed. A.
D. Michelson (London: Academic Press), 343-366.

Flaumenhaft, R., Dilks, J. R., Rozenvayn, N., Monahan-Earley, R. A., Feng, D., and Dvorak, A. M (2005). The actin cytoskeleton differentially regulates platelet alpha-granule and dense-granule secretion. Blood 105, 3879-3887. doi:10.1182/blood-2004-04-1392

Fukami, M. H., Holmsen, H., and Ugurbil, K. (1984). Histamine uptake in pig platelets and isolated dense granules. Biochem. Pharmacol. 33, 3869-3874. doi:10.1016/0006-2952(84)90053-4

Fulop, T., Doreian, B., and Smith, C. (2008). Dynamin I plays dual roles in the activity-dependent shift in exocytic mode in mouse adrenal chromaffin cells. Arch. Biochem. Biophys. 477, 146-154. doi:10.1016/j.abb.2008.04.039

Garcia, A. G., Garcia-de-Diego, A. M., Gandia, L., Borges, R., and GarciaSancho, J. (2006). Calcium signaling and exocytosis in adrenal chromaffin cells. Physiol. Rev. 86, 1093-1131. doi:10.1152/physrev.00039.2005

Ge, S., White, J. G., and Haynes, C. L. (2009). Quantal release of serotonin from platelets. Anal. Chem. 81, 2935-2943. doi:10.1021/ ac8024202

Ge, S., White, J. G., and Haynes, C. L. (2010). Critical role of membrane cholesterol in exocytosis revealed by single platelet study. ACS Chem. Biol. 5, 819-828. doi:10.1021/cb100130b

Ge, S., Wittenberg, N. J., and Haynes, C. L. (2008). Quantitative and real-time detection of secretion of chemical messengers from individual platelets. Biochemistry 47, 7020-7024. doi:10.1021/bi800792m

Gerber, S. H., Rah, J. C., Min, S. W., Liu, X., de Wit, H., Dulubova, I., et al. (2008). Conformational switch of syntaxin-1 controls synaptic vesicle fusion. Science 321, 1507-1510. doi:10.1126/science.1163174

Gieger, C., Radhakrishnan, A., Cvejic, A., Tang, W., Porcu, E., Pistis, G., et al. (2011). New gene functions in megakaryopoiesis and platelet formation. Nature 480, 201-208. doi:10.1038/nature10659

Gillitzer, A., Peluso, M., Bultmann, A., Munch, G., Gawaz, M., and Ungerer, M. (2008). Effect of dominant negative SNAP-23 expression on platelet function. J. Thromb. Haemost. 6, 1757-1763. doi:10.1111/j.15387836.2008.03108.x

Ginsberg, M. H., Taylor, L., and Painter, R. G. (1980). The mechanism of thrombin-induced platelet factor 4 secretion. Blood 55, 661-668.
Gonzalez-Jamett, A. M., Baez-Matus, X., Hevia, M. A., Guerra, M. J. Olivares, M. J., Martinez, A. D. et al. (2010). The association of dynamin with synaptophysin regulates quantal size and duration of exocytotic events in chromaffin cells. J. Neurosci. 30, 10683-10691. doi:10.1523/JNEUROSCI.521009.2010

Graham, G. J., Ren, Q., Dilks, J. R., Blair, P., Whiteheart, S. W., and Flaumenhaft, R. (2009). Endobrevin/VAMP-8dependent dense granule release mediates thrombus formation in vivo. Blood 114, 1083-1090. doi:10.1182/blood-2009-03-210211

Graham, G. J., Stevens, J. M., Page, N. M., Grant, A. D., Brain, S. D., Lowry, P. J., et al. (2004). Tachykinins regulate the function of platelets. Blood 104, 1058-1065. doi:10.1182/blood2003-11-3979

Graham, M. E., O'Callaghan, D. W. McMahon, H. T., and Burgoyne, R. D. (2002). Dynamin-dependent and dynamin-independent processes contribute to the regulation of single vesicle release kinetics and quantal size. Proc. Natl. Acad. Sci. U.S.A. 99, 7124-7129. doi:10.1073/pnas.102645099

Gu, C., Yaddanapudi, S., Weins, A., Osborn, T., Reiser, J., Pollak, M., et al. (2010). Direct dynamin-actin interactions regulate the actin cytoskeleton. EMBO J. 29, 3593-3606. doi:10.1038/emboj.2010.249

Guan, R., Dai, H., and Rizo, J. (2008). Binding of the Munc13-1 MUN domain to membrane-anchored SNARE complexes. Biochemistry 47, 1474-1481. doi:10.1021/ bi702345m

Gulyas-Kovacs, A., de Wit, H., Milosevic, I., Kochubey, O., Toonen, R., Klingauf, J., et al. (2007). Munc18-1: sequential interactions with the fusion machinery stimulate vesicle docking and priming. J. Neurosci. 27, 8676-8686. doi:10.1523/JNEUROSCI.065807.2007

Gutierrez, L. M., Quintanar, J. L., Viniegra, S., Salinas, E., Moya, F., and Reig, J. A. (1995). Antisyntaxin antibodies inhibit calcium-dependent catecholamine secretion from permeabilized chromaffin cells. Biochem. Biophys. Res. Commun. 206, 1-7. doi:10.1006/bbrc. 1995.1001

Hata, Y., Slaughter, C. A., and Sudhof, T. C. (1993). Synaptic vesicle fusion complex contains unc-18 homologue bound to syntaxin. Nature 366, 347-351. doi:10.1038/366347a0
Hermansky, F., and Pudlak, P. (1959). Albinism associated with hemorrhagic diathesis and unusual pigmented reticular cells in the bone marrow: report of two cases with histochemical studies. Blood 14 162-169.

Holmsen, H., and Weiss, H. J. (1979). Secretable storage pools in platelets. Annu. Rev. Med. 30, 119-134. doi:10.1146/ annurev.me.30.020179.001003

Houng, A., Polgar, J., and Reed, G. L. (2003). Munc18-syntaxin complexes and exocytosis in human platelets. J. Biol. Chem. 278, 19627-19633. doi:10.1074/jbc.M212465200

Ishii, E., Ueda, I., Shirakawa, R., Yamamoto, K., Horiuchi, H., Ohga, S., et al. (2005). Genetic subtypes of familial hemophagocytic lymphohistiocytosis: correlations with clinical features and cytotoxic $\mathrm{T}$ lymphocyte/natural killer cell functions. Blood 105, 3442-3448. doi:10.1182/blood-2004-08-3296

Italiano, J. E. Jr., Richardson, J. L., PatelHett, S., Battinelli, E., Zaslavsky, A., Short, S., et al. (2008). Angiogenesis is regulated by a novel mechanism: pro- and antiangiogenic proteins are organized into separate platelet \{alpha\} granules and differentially released. Blood 111, 1227-1233 doi:10.1182/blood-2007-09-113837

Jahn, R., and Scheller, R. H. (2006). SNAREs - engines for membrane fusion. Nat. Rev. Mol. Cell Biol. 7, 631-643. doi:10.1038/nrm2002

Jedlitschky, G., Tirschmann, K., Lubenow, L. E., Nieuwenhuis, H. K., Akkerman, J. W., Greinacher, A., et al. (2004). The nucleotide transporter MRP4 (ABCC4) is highly expressed in human platelets and present in dense granules, indicating a role in mediator storage. Blood 104, 3603-3610. doi:10.1182/blood-2003-12-4330

Khvotchev, M., Dulubova, I., Sun, J., Dai, H., Rizo, J., and Sudhof, T. C. (2007). Dual modes of Munc18-1/SNARE interactions are coupled by functionally critical binding to syntaxin-1 $\mathrm{N}$ terminus. J. Neurosci. 27, 12147-12155. doi:10.1523/JNEUROSCI.365507.2007

Knight, D. E., and Baker, P. F. (1985). The chromaffin granule proton pump and calcium-dependent exocytosis in bovine adrenal medullary cells. J. Membr. Biol. 83, 147-156. doi:10.1007/BF01868746

Knight, D. E., Hallam, T. J., and Scrutton, M. C. (1982). Agonist selectivity and second messenger concentration in $\mathrm{Ca} 2+$-mediated 
secretion. Nature 296, 256-257. doi:10.1038/296256a0

Knight, D. E., and Scrutton, M. C. (1980). Direct evidence for a role for $\mathrm{Ca} 2+$ in amine storage granule secretion by human platelets. Thromb. Res. 20, 437-446. doi:10.1016/0049-3848(80)90282-0

Knight, D. E., Sugden, D., and Baker, P. F. (1988). Evidence implicating protein kinase $\mathrm{C}$ in exocytosis from electropermeabilized bovine chromaffin cells. J. Membr. Biol. 104, 21-34. doi:10.1007/BF01871899

Knight, D. E., Tonge, D. A., and Baker, P. F. (1985). Inhibition of exocytosis in bovine adrenal medullary cells by botulinum toxin type D. Nature 317, 719-721. doi:10.1038/317719a0

Koseoglu, S., Dilks, J. R., Peters, C. G., Fitch, J. L., Fadel, N. A., Jasuja, R., et al. (2013). Dynaminrelated protein-1 controls fusion pore dynamics during platelet granule exocytosis. Arterioscler. Thromb. Vasc. Biol. 33, 481-488. doi:10.1161/ATVBAHA.112.255737

Koval, L. M., Yavorskaya, E. N., and Lukyanetz, E. A. (2001). Electron microscopic evidence for multiple types of secretory vesicles in bovine chromaffin cells. Gen. Comp. Endocrinol. 121, 261-277. doi:10.1006/gcen.2000.7592

Lemons, P. P., Chen, D., and Whiteheart, S. W. (2000). Molecular mechanisms of platelet exocytosis: requirements for alpha-granule release. Biochem. Biophys. Res. Commun. 267, 875-880. doi:10.1006/bbrc.1999.2039

Livett, B. G. (1993). Chromaffin cells: roles for vesicle proteins and $\mathrm{Ca} 2+$ in hormone secretion and exocytosis. Trends Pharmacol. Sci. 14, 345-348. doi:10.1016/01656147(93)90090-7

Marcu, M. G., Zhang, L., Nau-Staudt, K., and Trifaro, J. M. (1996). Recombinant scinderin, an F-actin severing protein, increases calcium-induced release of serotonin from permeabilized platelets, an effect blocked by two scinderin-derived actin-binding peptides and phosphatidylinositol 4,5-bisphosphate. Blood 87, 20-24.

Martinez-Arca, S., Alberts, P., Zahraoui, A., Louvard, D., and Galli, T. (2000). Role of tetanus neurotoxin insensitive vesicle-associated membrane protein (TI-VAMP) in vesicular transport mediating neurite outgrowth. J. Cell Biol. 149, 889-900. doi:10.1083/jcb.149.4.889

Martinez-Arca, S., Coco, S., Mainguy, G., Schenk, U., Alberts, P., Bouille, P., et al. (2001). A common exocytotic mechanism mediates axonal and dendritic outgrowth. J. Neurosci. 21, 3830-3838.

Matsuoka, H., Harada, K., Nakamura, J., Fukuda, M., and Inoue, M. (2011). Differential distribution of synaptotagmin-1, $-4,-7$, and -9 in rat adrenal chromaffin cells. Cell Tissue Res. 344, 41-50. doi:10.1007/s00441011-1131-8

Morgenstern, E., Neumann, K., and Patscheke, H. (1987). The exocytosis of human blood platelets. A fast freezing and freeze-substitution analysis. Eur. J. Cell Biol. 43, 273-282.

Penner, R., and Nicher, E. (1988). The role of calcium in stimulussecretion coupling in excitable and non-excitable cells. J. Exp. Biol. 139, 329-345.

Perrais, D., Kleppe, I., Taraska, J., and Almers, W. (2004). Recapture after exocytosis causes differential retention of protein in granules of bovine chromaffin cells. J. Physiol. 560, 413-428. doi:10.1113/jphysiol.2004.064410

Peters, C. G., Michelson, A. D., and Flaumenhaft, R. (2012). Granule exocytosis is required for platelet spreading: differential sorting of alphagranules expressing VAMP-7. Blood 120, 199-206. doi:10.1182/blood2011-10-389247

Pevsner, J., Hsu, S. C., and Scheller, R. H. (1994). n-Secl: a neural-specific syntaxin-binding protein. Proc. Natl. Acad. Sci. U.S.A. 91, 1445-1449. doi:10.1073/pnas.91.4.1445

Piersma, S. R., Broxterman, H. J., Kapci, M., de Haas, R. R., Hoekman, K., Verheul, H. M., et al. (2009). Proteomics of the TRAP-induced platelet releasate. J. Proteomics 72, 91-109. doi:10.1016/j.jprot.2008.10.009

Rathore, S. S., Bend, E. G., Yu, H., Hammarlund, M., Jorgensen, E. M., and Shen, J. (2010). Syntaxin Nterminal peptide motif is an initiation factor for the assembly of the SNARE-Sec1/Munc18 membrane fusion complex. Proc. Natl. Acad. Sci. U.S.A. 107, 22399-22406. doi:10.1073/pnas.1012997108

Reems, J. A., Wang, W., Tsubata, K., Abdurrahman, N., Sundell, B., Tijssen, M. R., et al. (2008). Dynamin 3 participates in the growth and development of megakaryocytes. Exp. Hematol. 36, 1714-1727. doi:10.1016/j.exphem.2008.08.010

Ren, Q., Barber, H. K., Crawford, G. L., Karim, Z. A., Zhao, C., Choi, W., et al. (2007). Endobrevin/VAMP-8 is the primary $\mathrm{v}$-SNARE for the platelet release reaction. Mol. Biol. Cell 18, 24-33. doi:10.1091/mbc.E06-090785
Ren, Q., Wimmer, C., Chicka, M. C., Ye, S., Ren, Y., Hughson, F. M., et al. (2010). Munc13-4 is a limiting factor in the pathway required for platelet granule release and hemostasis. Blood 116, 869-877. doi:10.1182/blood-2010-02-270934

Rosenmund, C., Sigler, A., Augustin, I., Reim, K., Brose, N., and Rhee, J. S. (2002). Differential control of vesicle priming and short-term plasticity by Munc13 isoforms. Neuron 33, 411-424. doi:10.1016/S08966273(02)00568-8

Rothman, J. E., and Orci, L. (1992). Molecular dissection of the secretory pathway. Nature 355, 409-415. doi:10.1038/355409a0

Ruiz, F. A., Lea, C. R., Oldfield, E., and Docampo, R. (2004). Human platelet dense granules contain polyphosphate and are similar to acidocalcisomes of bacteria and unicellular eukaryotes. J. Biol. Chem. 279, 44250-44257. doi:10.1074/jbc.M406261200

Sassa, T., Harada, S., Ogawa, H., Rand, J. B., Maruyama, I. N., and Hosono, R. (1999). Regulation of the UNC18-Caenorhabditis elegans syntaxin complex by UNC-13. J. Neurosci. 19, 4772-4777.

Sawada, K., Echigo, N., Juge, N., Miyaji, T., Otsuka, M., Omote, H., et al. (2008). Identification of a vesicular nucleotide transporter. Proc. Natl. Acad. Sci. U.S.A. 105, 5683-5686. doi:10.1073/pnas.0800141105

Schiavo, G., Benfenati, F., Poulain, B., Rossetto, O., Polverino de Laureto, P., DasGupta, B. R., et al. (1992). Tetanus and botulinum-B neurotoxins block neurotransmitter release by proteolytic cleavage of synaptobrevin [see comments]. Nature 359, 832-835. doi:10.1038/ $359832 \mathrm{a} 0$

Schraw, T. D., Lemons, P. P., Dean, W. L., and Whiteheart, S. W. (2003). A role for Sec1/Munc18 proteins in platelet exocytosis. Biochem. J. 374, 207-217. doi:10.1042/BJ20030610

Schutz, D., Zilly, F., Lang, T., Jahn, R., and Bruns, D. (2005). A dual function for Munc-18 in exocytosis of PC12 cells. Eur. J. Neurosci. 21, 2419-2432. doi:10.1111/j.14609568.2005.04095. $\mathrm{x}$

Sehgal, S., and Storrie, B. (2007). Evidence that differential packaging of the major platelet granule proteins von Willebrand factor and fibrinogen can support their differential release. J. Thromb. Haemost. 5, 2009-2016. doi:10.1111/j.15387836.2007.02698.x

Shirakawa, R., Higashi, T., Tabuchi, A., Yoshioka, A., Nishioka, H.,
Fukuda, M., et al. (2004). Munc13-4 is a GTP-Rab27-binding protein regulating dense core granule secretion in platelets. $J$. Biol. Chem. 279, 10730-10737. doi:10.1074/jbc.M309426200

Sigel, H., and Corfu, N. A. (1996). The assisted self-association of ATP4- by a poly(amino acid) [poly(Lys)] and its significance for cell organelles that contain high concentrations of nucleotides. Eur. J. Biochem 240, 508-517. doi:10.1111/j.14321033.1996.0508h.x

Sim, D. S., Dilks, J. R., and Flaumenhaft, R. (2007). Platelets possess and require an active protein palmitoylation pathway for agonistmediated activation and in vivo thrombus formation. Arterioscler. Thromb. Vasc. Biol. 27, 1478-1485. doi:10.1161/ATVBAHA.106.139287

Sollner, T., Whiteheart, S. W., Brunner, M., Erdjument-Bromage, H., Geromanos, S., Tempst, P., et al. (1993). SNAP receptors implicated in vesicle targeting and fusion [see comments]. Nature 362, 318-324. doi:10.1038/362318a0

Song, Y., Ailenberg, M., and Silverman, M. (1998). Cloning of a novel gene in the human kidney homologous to rat munc13s: its potential role in diabetic nephropathy. Kidney Int 53, 1689-1695. doi:10.1046/j.15231755.1998.00942.x

Stenberg, P. E., Shuman, M. A., Levine, S. P., and Bainton, D. F. (1984). Redistribution of alpha-granules and their contents in thrombin-stimulated platelets. J. Cell Biol. 98, 748-760. doi:10.1083/jcb.98.2.748

Stevens, D. R., Wu, Z. X., Matti, U., Junge, H. J., Schirra, C., Becherer, U., et al. (2005). Identification of the minimal protein domain required for priming activity of Munc131. Curr. Biol. 15, 2243-2248. doi:10.1016/j.cub.2005.10.055

Tang, K. S., Tse, A., and Tse, F. W. (2005). Differential regulation of multiple populations of granules in rat adrenal chromaffin cells by culture duration and cyclic AMP. J. Neurochem. 92, 1126-1139. doi:10.1111/j.14714159.2004.02944.x

Trifaro, J. M., Lejen, T., Rose, S. D., Pene, T. D., Barkar, N. D. and Seward, E. P. (2002). Pathways that control cortical F-actin dynamics during secretion. Neurochem. Res. 27, 1371-1385. doi:10.1023/A:1021627800918

Tsuboi, T., McMahon, H. T., and Rutter, G. A. (2004). Mechanisms of dense core vesicle recapture following "kiss and run" ("cavicapture") 
exocytosis in insulin-secreting cells. J. Biol. Chem. 279, 47115-47124. doi:10.1074/jbc.M408179200

van Nispen tot Pannerden, H., De Haas, F., Geerts, W., Posthuma, G., Van Dijk, S., and Heijnen, H. F. G. (2010). The platelet interior revisited: electron tomography reveals tubular alpha-granule subtypes. Blood 116, 1147-1156. doi:10.1182/ blood-2010-02-268680

Voets, T., Toonen, R. F., Brian, E. C., de Wit, H., Moser, T., Rettig, J., et al. (2001). Munc18-1 promotes large dense-core vesicle docking. $\mathrm{Neu}$ ron 31, 581-591. doi:10.1016/S08966273(01)00391-9

Wang, W., Gilligan, D. M., Sun, S., Wu, X., and Reems, J. A. (2011). Distinct functional effects for dynamin 3 during megakaryocytopoiesis. Stem Cells Dev. 20, 2139-2151. doi:10.1089/ scd.2011.0159
Wegrzyn, J. L., Bark, S. J., Funkelstein, L., Mosier, C., Yap, A., KazemiEsfarjani, P., et al. (2010). Proteomics of dense core secretory vesicles reveal distinct protein categories for secretion of neuroeffectors for cell-cell communication. J. Proteome Res. 9, 5002-5024. doi:10.1021/pr 1003104

Wightman, R. M., and Haynes, C. L. (2004). Synaptic vesicles really do kiss and run. Nat. Neurosci. 7, 321-322. doi:10.1038/nn0404-321

Woronowicz, K., Dilks, J. R., Rozenvayn, N., Dowal, L., Blair, P. S., Peters, C. G., et al. (2010). The platelet actin cytoskeleton associates with SNAREs and participates in alphagranule secretion. Biochemistry 49, 4533-4542. doi:10.1021/bi10 $0541 \mathrm{t}$

Xu, T., Binz, T., Niemann, H., and Neher, E. (1998). Multiple kinetic components of exocytosis distinguished by neurotoxin sensitivity. Nat. Neurosci. 1, 192-200. doi:10.1038/642

Yang, B., Steegmaier, M., Gonzalez, L. C. Jr., and Scheller, R. H. (2000). nSec1 binds a closed conformation of syntaxin1A. J. Cell Biol. 148, 247-252. doi:10.1083/jcb.148.2.247

Ye, S., Karim, Z. A., Al Hawas, R., Pessin, J. E., Filipovich, A. H., and Whiteheart, S. W. (2012). Syntaxin-11, but not syntaxin- 2 or syntaxin- 4 , is required for platelet secretion. Blood 120, 2484-2492. doi:10.1182/blood2012-05-430603

Zhang, X., Kim-Miller, M. J., Fukuda, M., Kowalchyk, J. A., and Martin, T. F. (2002). Ca2+-dependent synaptotagmin binding to SNAP-25 is essential for Ca2+-triggered exocytosis. Neuron 34, 599-611. doi:10. 1016/S0896-6273(02)00671-2

Conflict of Interest Statement: The authors declare that the research was conducted in the absence of any commercial or financial relationships that could be construed as a potential conflict of interest.

Received: 17 April 2013; accepted: 11 June 2013; published online: 26 June 2013.

Citation: Fitch-Tewfik JL and Flaumenhaft $R$ (2013) Platelet granule exocytosis: a comparison with chromaffin cells. Front. Endocrinol. 4:77. doi: 10.3389/fendo.2013.00077

This article was submitted to Frontiers in Neuroendocrine Science, a specialty of Frontiers in Endocrinology.

Copyright $\odot 2013$ Fitch-Tewfik and Flaumenhaft. This is an open-access article distributed under the terms of the Creative Commons Attribution License, which permits use, distribution and reproduction in other forums, provided the original authors and source are credited and subject to any copyright notices concerning any third-party graphics etc. 